Article

\title{
Immobilization of Mucor miehei Lipase onto Macroporous Aminated Polyethersulfone Membrane for Enzymatic Reactions
}

\author{
Nurrahmi Handayani ${ }^{1{ }_{*}, \text { Katja Loos }}{ }^{2}$, Deana Wahyuningrum ${ }^{1}$, Buchari ${ }^{1}$ and \\ Muhammad Ali Zulfikar ${ }^{1}$
}

1 Chemistry Study Program, Institute Technology of Bandung, Jalan Ganesha No. 10 Bandung 40132, Indonesia; E-Mails: deana@chem.itb.ac.id (D.W.); buchari@chem.itb.ac.id (B.); zulfikar@chem.itb.ac.id (M.A.Z.)

2 Department of Polymer Chemistry \& Zernike Institute for Advanced Materials, University of Groningen, Nijenborg 4, 9747 AG, The Netherlands; E-Mail: k.u.loos@rug.nl

* Author to whom correspondence should be addressed; E-Mail: nurrahmi.105@gmail.com; Tel.: +62-81-321-388-745; Fax: +62-22-2504154.

Received: 6 February 2012; in revised form: 28 March 2012 / Accepted: 29 March 2012 / Published: 12 April 2012

\begin{abstract}
Immobilization of enzymes is one of the most promising methods in enzyme performance enhancement, including stability, recovery, and reusability. However, investigation of suitable solid support in enzyme immobilization is still a scientific challenge. Polyethersulfone (PES) and aminated PES (PES- $\left.\mathrm{NH}_{2}\right)$ were successfully synthesized as novel materials for immobilization. Membranes with various pore sizes (from 10-600 nm) based on synthesized PES and PES- $\mathrm{NH}_{2}$ polymers were successfully fabricated to be applied as bioreactors to increase the immobilized lipase performances. The influence of pore sizes, concentration of additives, and the functional groups that are attached on the PES backbone on enzyme loading and enzyme activity was studied. The largest enzyme loading was obtained by Mucor miehei lipase immobilized onto a PES- $\mathrm{NH}_{2}$ membrane composed of $10 \%$ of PES- $\mathrm{NH}_{2}, 8 \%$ of dibutyl phthalate (DBP), and $5 \%$ of polyethylene glycol (PEG) $\left(872.62 \mu \mathrm{g} / \mathrm{cm}^{2}\right)$. Hydrolytic activity of the immobilized lipases indicated that the activities of biocatalysts are not significantly decreased by immobilization. From the reusability test, the lipase immobilized onto PES- $\mathrm{NH}_{2}$ showed a better constancy than the lipase immobilized onto PES (the percent recovery of the activity of the lipases immobilized onto PES- $\mathrm{NH}_{2}$ and $\mathrm{PES}$ are $97.16 \%$ and $95.37 \%$, respectively), which indicates that this novel material has the potential to be developed as a bioreactor for enzymatic reactions.
\end{abstract}


Keywords: aminated PES; solid support; Mucor miehei; enzymatic reactions; lipase immobilization

\section{Introduction}

Immobilized enzymes are becoming more important for catalyzed reactions because they show good reusability of enzyme, reduce the operation and production costs, and display high-efficiency in controlling catalytic activity [1-3]. The insoluble immobilized enzyme technique has been developed in various applications such as heterogeneous biocatalysts, selective adsorbents, protein drug releases, analytical devices, and solid phase protein development [4-8]. In addition to its attractive properties, a common problem in the immobilization of enzymes is the blocking of enzyme active sites because of the interaction between the enzyme and its solid support $[9,10]$. However, this interaction depends on the size of the lid of the enzyme and the substrate size. The blocking of the active site by immobilization only occurs if the substrate is sufficiently large [11,12]. Moreover, the lid will be opened and the active site of the enzyme will be exposed to the medium in a hydrophobic environment. The opening of the active site of the enzyme in a hydrophilic environment (e.g., an aqueous buffer) hardly occurs [13-15]. Enzyme distortion is a common effect of immobilization, however in some cases it is associated to an intense stabilization by multisubunits and multipoint attachment or generation of an adequate immobilization system [11,16-21].

Enzymes immobilized onto a membrane as bioreactor offer several benefits, such as a high specific surface area, good reusability, straightforward substrate and product separation on a single unit, and reduction in waste. This technique also shows high operational stability in continuous systems compared to immobilized enzymes on beads [22]. Enzyme attachment onto membranes can take place by: (1) adsorption by van der Waals' interaction towards a hydrophobic solid support (e.g., polypropylene and Teflon), (2) ionic bonding towards an ion-exchanger solid support (e.g., DEAE cellulose, DEAE Sephadex, and carboxymethyl cellulose (CMC)), or (3) covalent attachment between the amino or carboxyl groups of proteins and a membrane as support. Covalent immobilization is highly stable, but limited because of the denaturation of native enzyme during the binding process or decrease of enzyme activity after attachment [23-25].

One of the potential polymeric materials as a solid support for lipase is Polyethersulfone (PES) due to its good thermal stability, great mechanical resistance, and high resistance towards various chemicals with extreme properties [26]. The structure of PES will mediate the physical interfacial interaction (the simplest technique in enzyme immobilization) between the enzyme and the polymer [27]. In this research, we propose a new immobilized lipase reactor-based modified PES. The presence of an amino group contributes greatly towards the strong interaction between enzyme and its solid support by hydrophilic-hydrophilic interaction, ionic bonding, and can even initiate the formation of covalent attachment [28].

Lipase is a carboxylesterase, the most common enzyme for catalyzed-hydrolysis reactions and the synthesis of long chain acyl glycerol. Lipase properties, such as high chemo-selectivity, stereo-selectivity, regio-selectivity, and the fact that it does not require a cofactor during reaction, 
render it a widely-used biocatalyst for various reactions [29]. The mechanism of lipase activity is directed by a "catalytic triad" made up of serine, histidine, and aspartate/glutamate in the active center [30]. Acyl groups on the active side can accommodate the chiral enantiomer of the acyl group and facilitate a better binding compared to the alcohol group. In addition, the stereoselectivity of the acyl group to the substrate is higher than the alcohol group. Based on its properties, the lipase can potentially be developed in a variety of biotechnological applications. For example, lipase can be used to produce biosurfactant [31], fatty acids [32], lubricating oils and solvents [33], aroma and taste synthetics [34], polyesters [35], and thiol esters [36].

Lipase from Mucor miehei is the most efficient catalyst for the transesterification and hydrolysis reaction involving a primary alcohol [23], and it demonstrates high activity in various organic solvents [37]. This enzyme contains one helix (operating as a lid) protecting the active center and which will open during activation [12,38]. Mucor miehei displays the optimum yield when the reaction temperature is kept in a range of $50-60{ }^{\circ} \mathrm{C}$ in a $\mathrm{pH} 7$ buffer solution [29]. Because of its good performance under mild conditions involving a primary alcohol, Mucor miehei lipase was chosen to be used in this study, and the activities of free lipase and immobilized lipase were investigated. The characteristics of immobilized Mucor miehei onto PES and PES- $\mathrm{NH}_{2}$ membranes using various concentrations of additives were also evaluated. By this study, it is hoped that the modification of PES can increase the strength of the enzyme-solid support interactions without decreasing enzyme activity, and that it becomes the potential bioreactor for enzymatic reactions.

\section{Results and Discussion}

\subsection{Synthesized Polyethersulfone}

Polymerization is one of the crucial steps to produce a high performance solid support. PES was synthesized as the precursor of $\mathrm{PES}-\mathrm{NH}_{2}$ by polycondensation between hydroquinone and 4,4'-dichlorodiphenyl sulfone in a mixed solvent system of NMP and toluene with $\mathrm{K}_{2} \mathrm{CO}_{3}$ as an activator. $\mathrm{CO}_{2}$ gas is one of the side-products from the polymerization reaction, and it can be easily removed from the system. Meanwhile, $\mathrm{H}_{2} \mathrm{O}$ could be completely eliminated by a toluene-water azeotrope system $[39,40]$. Therefore, the reaction required a series of Dean-Stark traps that play an important role in the process of azeotropic distillation. In addition, a nitrogen flow during the synthesis process kept the system under inert conditions. A viscous solution indicated that the condensation reaction has been completed. The determination of the molecular mass of PES by MALDI-TOF spectrometry was difficult to perform because PES is only soluble in NMP, a thick and non-volatile solvent. However, by using the appropriate conditions and matrix, MALDI-TOF could be performed to determine the mass of the PES repeating unit. The repeating unit mass of the synthesized PES based on the MALDI-TOF measurement was $324 \mathrm{Da}(\mathrm{m} / \mathrm{z})$ as shown in Figure 1.

Based on the 1H NMR spectrum, chemical shifts between 7.01 and $7.89 \mathrm{ppm}$ correspond to the aromatic protons of PES positioned close to the ether linkage $(-\mathrm{O}-)$ or sulfone group $\left(-\mathrm{SO}_{2}-\right)$. Characteristic peaks in the FTIR spectrum at wave-numbers of $1327.7,1156.7$, and $1282.1 \mathrm{~cm}-1$ indicated the presence of $\mathrm{C}-\mathrm{O}-\mathrm{C}$ and $-\mathrm{SO}_{2}$ functional groups within the structure of the product. 
According to the results and the data analysis, the structure of synthesized PES is described as shown in Figure 2.

Figure 1. MALDI-TOF spectrum of the synthesized PES.

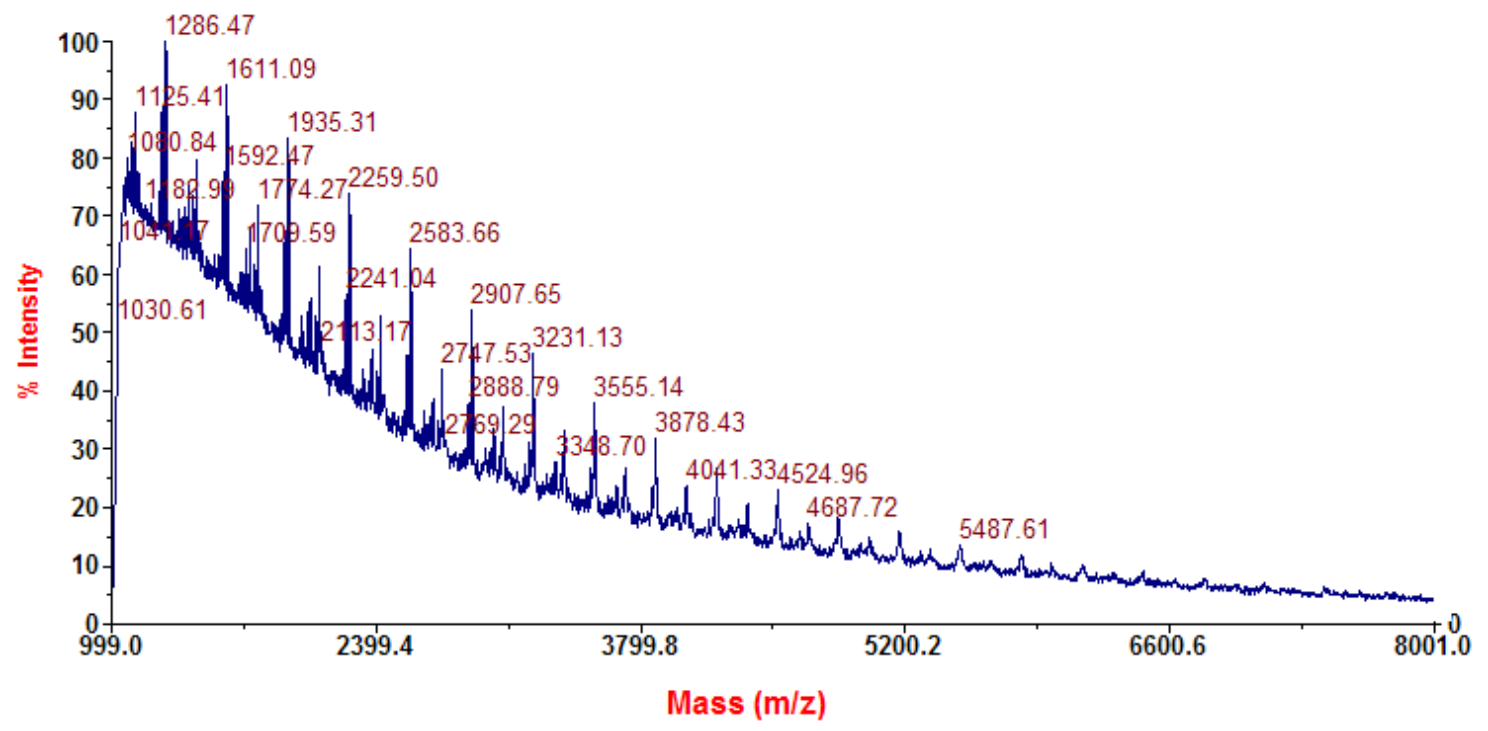

Figure 2. Structure of synthesized PES (upper) and aminated PES (lower).

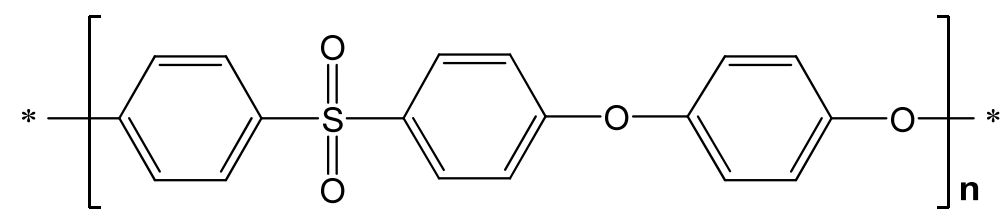

1) $\mathrm{HNO}_{3}$ (conctd), $\mathrm{H}_{2} \mathrm{SO}_{4}$ (conctd)

2) $\mathrm{SnCl}_{2} \cdot 2 \mathrm{H}_{2} \mathrm{O}: \mathrm{Nal}(30: 1)$

in $\mathrm{HCl}: \mathrm{HOAc}$ glacial $(2: 1)$

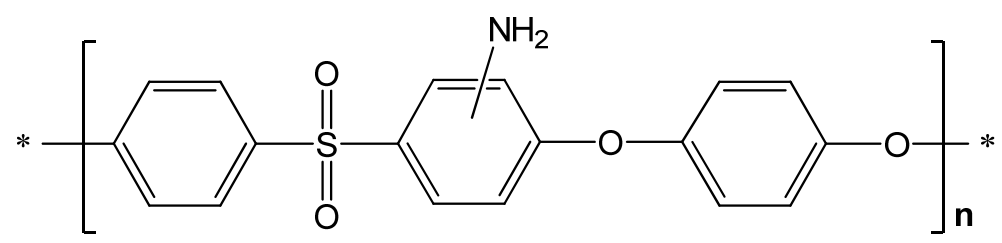

Based on its structure, polyethersulfone has hydrophobic groups that could increase membrane fouling and result in a higher energy demand, shorter membrane lifetime, and unpredictable separation lifetime [41]. The solubility of the synthesized PES was very specific because it only dissolved in heated NMP. The molecular weight, end groups, and purity of the polymer strongly affect the solubility properties. Modification of PES by amination of PES is one of the most promising procedures to overcome these problems by increasing its hydrophilicity. The presence of amino $\left(-\mathrm{NH}_{2}\right)$ functional groups in the polymer backbone could mediate the strong physical interactions through hydrophilic-hydrophilic interaction or ionic bonding with the enzyme. Therefore, the reusability of immobilized lipase will increase [28].

Based on the FTIR spectrum, a characteristic peak at the wave-number of $3087.1 \mathrm{~cm}^{-1}$ (double bands) indicated the presence of secondary amine moieties. Moreover, according to the ${ }^{1} \mathrm{H}-\mathrm{NMR}$ 
spectra, the signal with a chemical shift of $4.70 \mathrm{ppm}$ indicated the presence of $-\mathrm{NH}_{2}$ groups within the synthesized polymer. The glass transition temperatures $\left(T_{g}\right)$ of synthesized PES and PES- $\mathrm{NH}_{2}$ were $207.53{ }^{\circ} \mathrm{C}$ and $211.27{ }^{\circ} \mathrm{C}$, respectively. The amino groups on $\mathrm{PES}-\mathrm{NH}_{2}$ lead to stronger conformation of the polymer compared to the PES without modification, because of the steric hindrance effect and intramolecular hydrogen interaction of $-\mathrm{NH}_{2}$ functional groups within the $\mathrm{PES}-\mathrm{NH}_{2}$ structures. Therefore, the decomposition of $\mathrm{PES}-\mathrm{NH}_{2}$ involves higher energy than unmodified PES, leading to the increase of thermal resistance of PES- $\mathrm{NH}_{2}$ compared to unmodified PES.

\subsection{Properties of Polyethersulfone Membranes}

Fabrication of the PES and PES- $\mathrm{NH}_{2}$ membranes was carried out by an inversion phase process. DBP was added to the casting solution as a plasticizer. In addition, PEG with a molecular weight of $2000 \mathrm{Da}(\mathrm{m} / \mathrm{z})$ was used as pore-size controller. The pore-size plays an important role in membrane performance, because an overly confined pore-size would cause limitation of diffusion and result in enzyme structure rearrangement and subsequent enzyme activity discharge. Contrariwise, very large pore-sizes would cause the clustering of enzymes leading to a decrease in activity. Suitable pore-size may lead to the efficient attachment of enzyme onto the solid support, thereby retaining its activity.

Based on scanning electron microscope (SEM) measurements (Figure 3), the porosity of the fabricated PES and PES- $\mathrm{NH}_{2}$ membranes vary from 10-600 $\mathrm{nm}$.

Figure 3. SEM image of membrane porosity with $40,000 \times$ magnification: (a) PES-10; (b) PES-10/D6; (c) PES-10/P4; (d) PESNH-10/D2/P5.
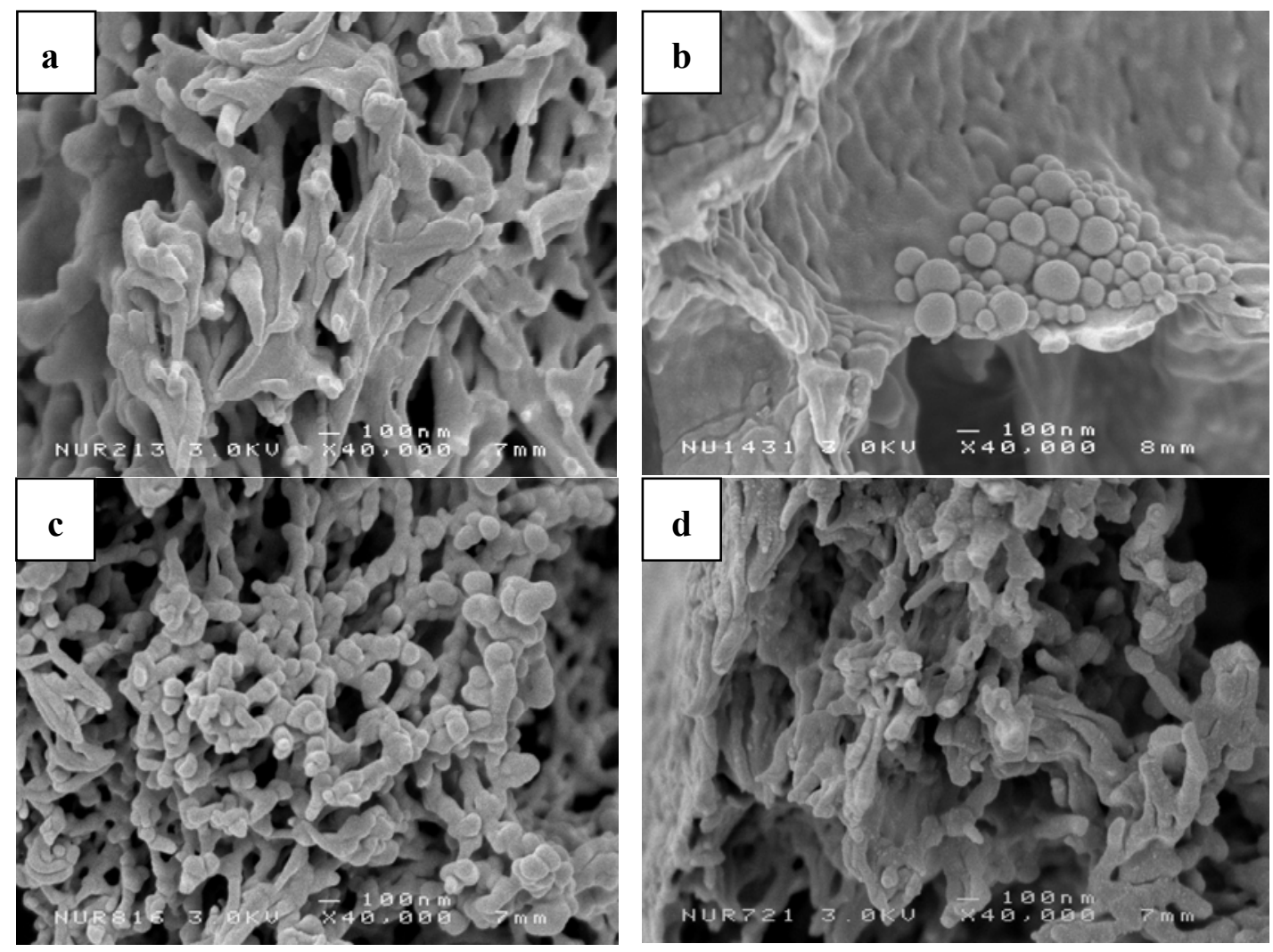
Figure 3 shows the influence of additives on the distribution of membrane porosity. By using DBP as plasticizer, the morphology of the membranes became dense and rigid. After DBP addition, the membranes showed an increased strength compared to the membranes without DBP. The presence of granules (identified as DBP molecules) appearing on the SEM image of PES-10/D6 (Figure 3b), indicate that DBP particles may affect the ability of the membrane to interact with the enzymes. On the other hand, addition of PEG would influence the pore-size distribution. From the SEM images, the distribution of pores within the PES membrane became more homogeneous and close-packed when PEG was added (Figure 3c). Homogeneous and close-packed membranes would influence the transport properties of membranes. Therefore, the addition of both DBP and PEG during membrane preparation is expected to increase the membrane's performances (highly permeable, good strength, and high elasticity).

Figure 4 shows the cross sections of PES-NH2 membrane with DBP and PEG present, compared to the PES membrane with DBP. DBP and PEG were combined to obtain a PES-NH2 membrane with a high potential to be applied as solid support in lipase immobilization. It is important to note that the addition of PEG during the membrane preparation leads to the diffusion of PEG from the casting solution to water as the coagulant, resulting in a homogenous porosity in the membranes. The pores in the membrane will influence enzyme immobilization, because the enzyme is not only attached to the surface of membrane, but also to the inner pores.

Figure 4. SEM photograph of the cross section of (a) PES10/D6 and (b) PESNH-10/D2/P5.
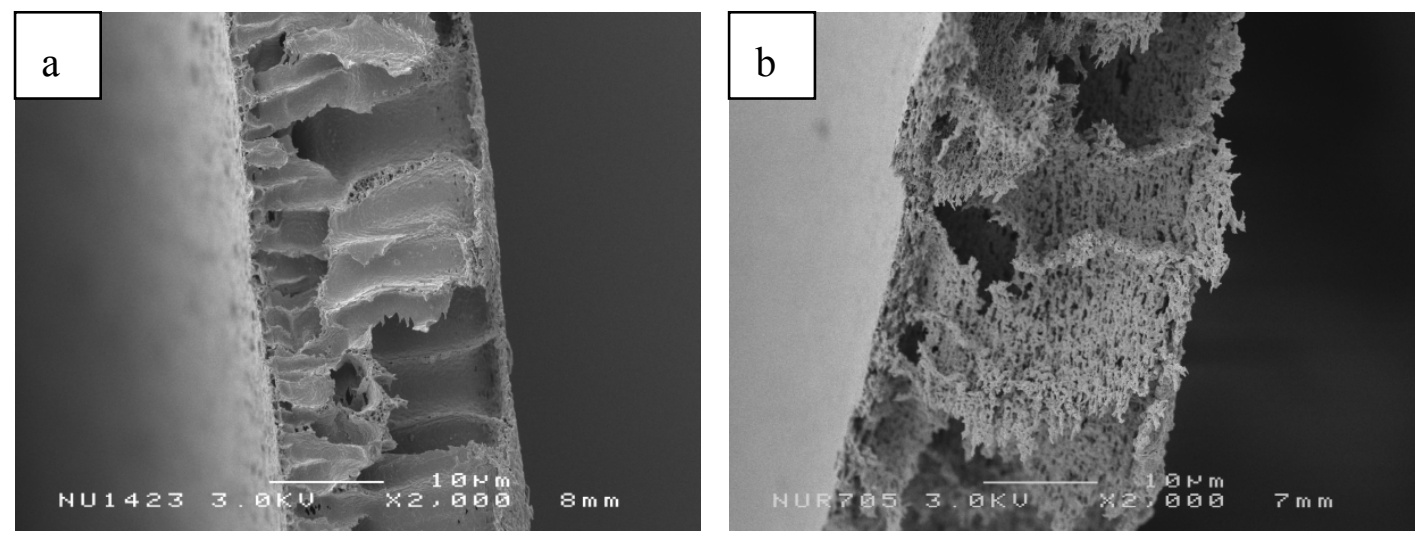

Based on the analysis of the SEM images, the membranes obtained form two layers (top layer and sub layer). The top layer has a smaller and denser pore-size than the sub layer, therefore indicating that the top layer plays an important role in membrane selectivity. Meanwhile, macro-voids that are present in the sub layer have a function as support and affect its mechanical strength of the membranes. Such membranes are known as asymmetric membrane, first developed by Loeb-Sourirajan [42].

\subsection{Immobilization of Mucor miehei Lipase}

The immobilization of Mucor miehei lipase was carried out in a rotary shaker for $24 \mathrm{~h}$ on $\mathrm{pH} 7 \mathrm{PBS}$ buffer (which is the optimum $\mathrm{pH}$ for Mucor miehei lipase). During the immobilization of Mucor miehei lipase onto the PES membranes, a physical interaction between the lipase and the solid 
support was formed. On the other hand, lipase immobilization onto the $\mathrm{PES}-\mathrm{NH}_{2}$ membranes gave rise to both physical interactions and chemical bonding between the lipase and its solid support.

Enzyme loading tests were performed to determine the amount of immobilized enzymes per membrane surface area. Protein determination has been carried out by a BCA protein assay. The enzyme loading of all immobilized Mucor miehei lipases onto the solid support is shown in Table 1.

Table 1. Enzyme loading for all immobilized Mucor miehei lipases.

\begin{tabular}{ccc}
\hline No. & Sample Code & Enzyme Loading * $\left(\boldsymbol{\mu g} / \mathbf{c m}^{\mathbf{2}}\right)$ \\
\hline 1. & PES-10 & $679.09 \pm 0.57$ \\
2. & ComPES-10 & $655.63 \pm 0.57$ \\
3. & PES-10/D4 & $667.35 \pm 0.57$ \\
4. & PES-10/D6 & $732.50 \pm 0.57$ \\
5. & PES-10/P4 & $718.78 \pm 0.57$ \\
6. & PES-10/P6 & $663.76 \pm 0.57$ \\
7. & PESNH-10/D5/P2 & $785.76 \pm 0.57$ \\
8. & PESNH-10/D5/P4 & $818.18 \pm 0.57$ \\
9. & PESNH-10/D5/P10 & $799.82 \pm 1.72$ \\
10. & PESNH-10/D2/P5 & $871.17 \pm 1.15$ \\
11. & PESNH-10/D4/P5 & $850.89 \pm 0.57$ \\
12. & PESNH-10/D8/P5 & $873.62 \pm 0.57$ \\
\hline
\end{tabular}

* Standard deviation values were calculated from three replicated experiments.

Based on these results, the enzyme loading is affected by the type and concentration of additives, and the functional groups along the polymer chain. The enzyme loading represents the amount of Mucor miehei lipase that is physically adsorbed or chemically attached to the polymer. In principle, the higher membrane porosity will increase the surface area for enzyme attachment leading to an increase in attached lipases. In this case, addition of DBP will increase the enzyme loading because of its properties as plasticizer. Looking at its structure, DBP has ester moieties that could form physical interactions with the enzyme [43]. Therefore, the addition of DBP during the membrane preparation will increase the enzyme loading.

On the other hand, the addition of PEG may increase the performance of immobilized enzymes. However, if the concentration of PEG is too high, homogeneity of the membrane porosity will increase, and the lipase will leach out from the solid support. Different functional groups on the polymer backbone would also give rise to a difference in enzyme loading. In this study, the presence of amine moieties increased the enzyme loading value. This indicates that strong physical interactions or ionic or covalent bonds between PES- $\mathrm{NH}_{2}$ and the lipase were formed, and that the majority of lipase was attached after washing. The optimum composition of the membrane, resulting in excellent enzyme loading, contains $10 \%$ of PES- $\mathrm{NH}_{2}, 8 \%$ of DBP, and $5 \%$ (w/w) of PEG.

The poor amount of enzyme loaded onto the solid support is caused by two things: (1) only the macroporous inner space is used for enzyme attachment, and (2) the incorporated enzyme molecules can exert a steric hindrance against the other enzyme molecule penetrations into the deeper macroporous region [44-47]. Therefore, according to this study, pore-size of membranes, 
concentration and the properties of additives, and covalent attachment contributor (functional groups) will influence the enzyme loading.

The interactions between PES- $\mathrm{NH}_{2}$ and lipase can be determined through the comparison of FT-IR spectra of PES- $\mathrm{NH}_{2}$ with spectra of lipase immobilized onto PES-- $\mathrm{NH}_{2}$ (Figure 5).

Figure 5. FT-IR spectra of PES- $\mathrm{NH}_{2}$ and lipases immobilized onto $\mathrm{PES}-\mathrm{NH}_{2}$, the black line is spectra of PES- $\mathrm{NH}_{2}$ and the red line is spectra of lipase immobilized onto PES- $\mathrm{NH}_{2}$.

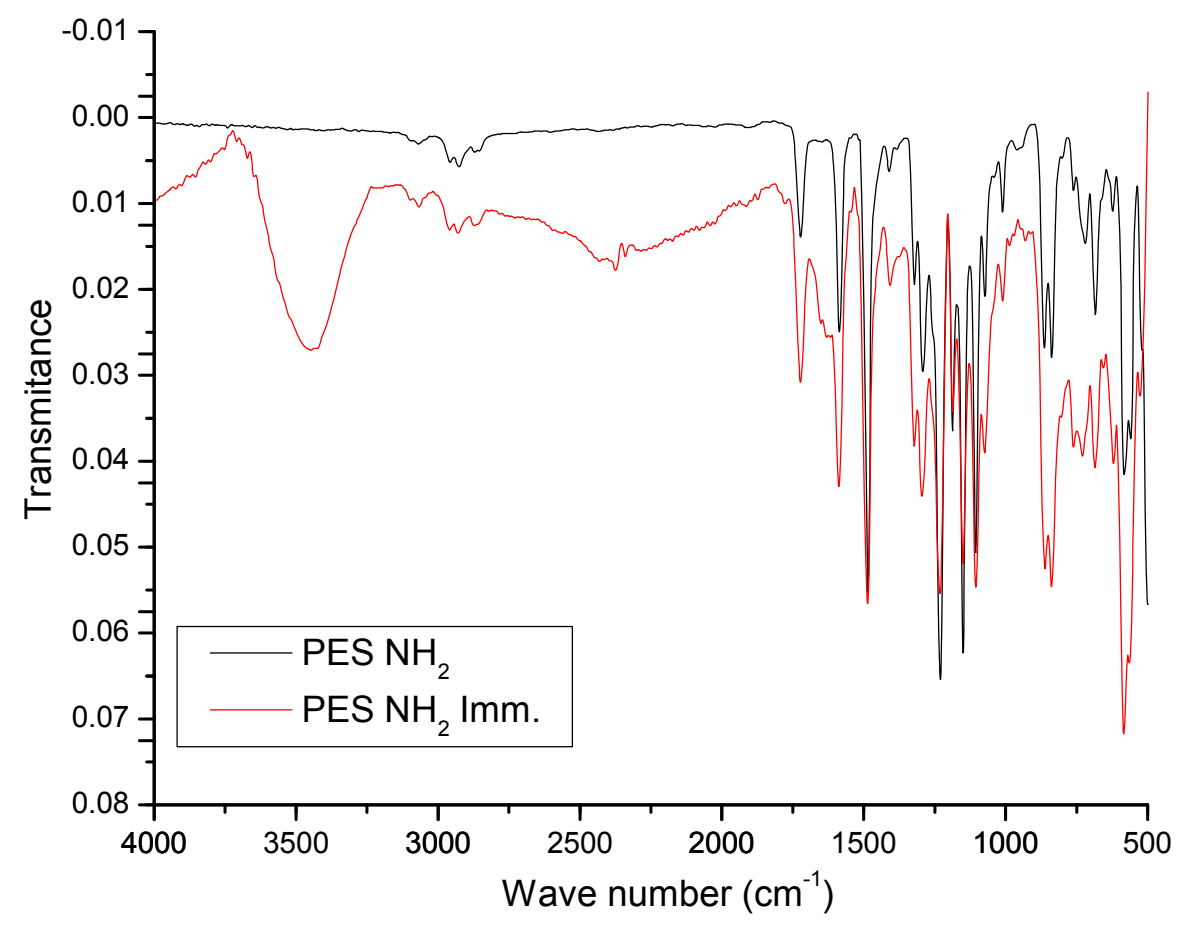

According to Figure 5, both PES- $\mathrm{NH}_{2}$ and lipase immobilized onto $\mathrm{PES}-\mathrm{NH}_{2}$ have comparable characteristic peaks, and it is the characteristic signal around $3450 \mathrm{~cm}^{-1}$ that identifies the existence of $-\mathrm{OH}$ functional groups. In other words, the lipase has been successfully attached to the polymer (the $-\mathrm{OH}$ functional groups relates to the $-\mathrm{COOH}$ terminal groups and amino acids residues, such as glutamic acid and aspartic acid). However, the amide bond is not present, considering the lipase and PES- $\mathrm{NH}_{2}$ interaction. The new characteristic peaks that represent $-\mathrm{C}-\mathrm{N}\left(\sim 1400 \mathrm{~cm}^{-1}\right),-\mathrm{N}-\mathrm{H}$ amide stretch $\left(3700-3500 \mathrm{~cm}^{-1}\right)$, and $\mathrm{C}=\mathrm{O}$ amide stretch $\left(1690-1630 \mathrm{~cm}^{-1}\right)$ [48] are not present in the spectra. These results indicate that lipases are physically adsorbed on the surface of the solid support.

\subsection{Hydrolytic Activity Test}

To evaluate the immobilized enzyme activity compared to the activity of the free enzyme, a series of lipase hydrolytic activity tests were performed. Hydrolytic activity tests were carried out by the conversion of $p$ NPA to $p \mathrm{NP}$, using methanol as an activator and 1,4-dioxane as a solvent. The reaction was carried out for $50 \mathrm{~min}$ at $50{ }^{\circ} \mathrm{C}$, which is the optimum temperature for Mucor miehei lipase, and the results are shown in Table 2. 
Table 2. Hydrolytic activity test result of Mucor miehei lipases.

\begin{tabular}{lcc}
\hline Sample Code & \% Yield & Activity* $\left.\mathbf{( m m o l} \boldsymbol{p} \mathbf{N P} \mathbf{~ m i n}^{-\mathbf{1}} \mathbf{c m}^{-\mathbf{2}}\right)$ \\
\hline Free & $27.93 \pm 0.07$ & $558.68 \pm 1.23$ \\
PESSynth 10P & $26.46 \pm 0.06$ & $529.27 \pm 1.22$ \\
PESSynth 10P 4D & $28.42 \pm 0.06$ & $568.48 \pm 1.22$ \\
PESComm 10P & $27.14 \pm 0.12$ & $542.75 \pm 2.44$ \\
PESComm 10P 4D & $26.22 \pm 0.07$ & $524.37 \pm 1.22$ \\
PNH2 10P 4D 5P & $25.85 \pm 0.07$ & $517.02 \pm 1.22$ \\
PNH2 10P 8D 5P & $25.73 \pm 0.07$ & $514.57 \pm 1.22$ \\
PNH2 10P 5D 2P & $24.50 \pm 0.06$ & $490.07 \pm 1.22$ \\
PNH2 10P 5D 4P & $26.10 \pm 0.06$ & $521.92 \pm 1.22$ \\
\hline
\end{tabular}

* Standard deviation values were calculated from three replicated experiments.

According to these results, the immobilization of the enzyme did not significantly decrease the activity of the enzyme, meaning that the active site of the enzyme was not disturbed by enzyme attachment onto the solid support. The addition of DBP to the casting solution during the membrane preparation increased the enzyme activity due to its presence on membrane pores, thereby increasing the selectivity of immobilized enzyme. Supposedly, the different synthesis procedure applied in this study, compared to the production of commercial PES, led to the difference in structures and textures, affecting the membrane porosity and other characteristics.

Strong physical interactions or ionic bonding, leading to the covalent attachment between lipases and the PES- $\mathrm{NH}_{2}$ membrane, have little impact on the product yield and hydrolysis activity of the enzyme. However, immobilized lipase on PES- $\mathrm{NH}_{2}$ membranes is one of the most promising enzyme immobilization techniques, because the solid support does not significantly reduce enzyme activity. Based on the results obtained, a higher composition of PEG leads to higher homogeneity and greater enzyme attachment. Therefore, the enzyme activity of immobilized lipase onto PES with the proper amount of PEG will increase.

\subsection{Reusability Test}

Reusability tests were performed to determine the ability of the immobilized enzyme to be reused. Higher reusability of the immobilized lipase will increase the economic value of the bio-reactor. The reusability of immobilized Mucor miehei lipase on a PES and PES- $\mathrm{NH}_{2}$ membrane, tested by a hydrolysis reaction between $p$ NPA and methanol, is represented in Figure 6.

After the completion of the enzyme activity test, the immobilized enzymes were washed several times with 1,4-dioxane and placed in vacuum overnight. Reusing the immobilized enzyme was carried out using the same procedures as the previous one. This procedure was repeated four times to check the reusability of the immobilized enzyme. Based on the results as shown in Figure 5, activity of immobilized enzyme on PES was decreased after repeating the experiments four times. Despite this, the activity of immobilized enzyme on PES-NH2 was quite constant. 
Figure 6. Profile of reusability test for immobilized enzyme on both PES and PES- $\mathrm{NH}_{2}$ membranes (repeated four times).

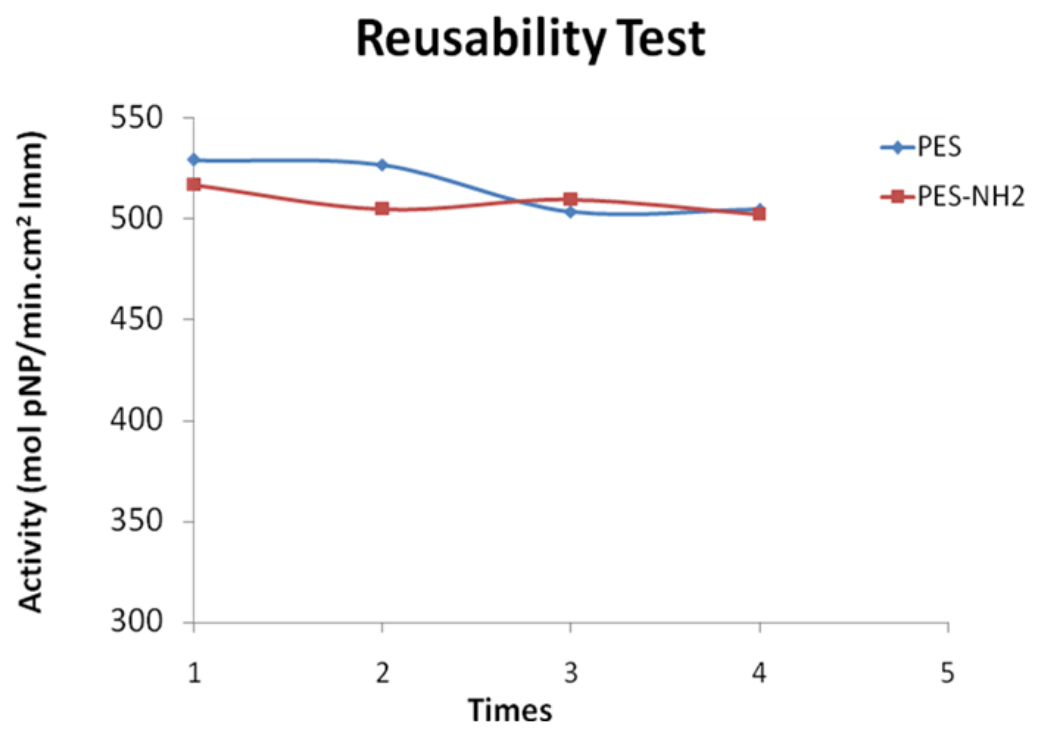

According to Figure 5, the immobilized enzymes display a much higher reusability than the free enzyme (the free enzyme shows zero reusability). The percent recovery of lipases immobilized onto PES- $\mathrm{NH}_{2}$ and PES are $97.16 \%$ and $95.37 \%$, respectively. Considering these values and the profile, the activity of immobilized lipase on PES- $\mathrm{NH}_{2}$ membrane is more constant than the immobilized lipase on a PES membrane. Therefore, it can be concluded that Mucor miehei lipase show higher reusability when immobilized on a PES- $\mathrm{NH}_{2}$ membrane, due to the presence of more and stronger interactions between the enzyme and the solid support system.

\section{Experimental Section}

\subsection{Materials and Methods}

Mucor miehei lipase in the form of brownish powder, hydroquinone $\left(\mathrm{C}_{6} \mathrm{H}_{6} \mathrm{O}_{2}\right)$, 4,4'-dichlorodiphenyl sulfone, potassium carbonate $\left(\mathrm{K}_{2} \mathrm{CO}_{3}\right)$, polyethylene glycol (PEG), $p$-nitrophenyl acetate ( $p$ NPA), and dibutyl phthalate (DBP) were purchased from Sigma-Aldrich. $\mathrm{N}$-Methyl Pyrrolidone (NMP) as solvent was supplied by Across Organics. Concentrated $\mathrm{H}_{2} \mathrm{SO}_{4}$, 99.8\% (w/w) methanol, and concentrated $\mathrm{HNO}_{3}$ were purchased from Lab-Scan Analytical Sciences. All the chemicals were of analytical grade and used without further purification. Commercial Polyethersulfone was supplied by BASF needed. BCA protein assay apparatus was purchased from Thermo Scientific.

Fourier transform infrared (FT-IR) and IR spectra of the polymers were obtained by JASCO FT/IR-5000 Spectrophotometer and Buck Scientific Model M-500 IR Spectrophotometer, respectively. Proton Nuclear Magnetic Resonance (1H-NMR) spectra was obtained in $d_{6}$-DMSO, by using a $400 \mathrm{MHz}$ VARIAN VXR NMR apparatus. The repeating unit of the obtained polymers was determined by Voyager-DE PRO MALDI-TOF spectrometer with $\alpha$-cyano-4-hydroxicinnamic acid. UV/VIS measurements were carried out on a PYE UNICAM SP8-200 UV/VIS spectrophotometer. 
Contents of carbon, hydrogen, oxygen and nitrogen in the obtained polymers were determined by Euro EA Elemental Analyzer (EuroVector).

\subsection{Synthesis of Polyethersulfone (PES)}

The synthesis of PES was developed from the procedures of Keitoku et al. and Handayani et al. applying major modifications [39,40]. In a $500 \mathrm{~mL}$ three-necked round bottom flask fitted with a Dean-Stark trap, a condenser, a nitrogen inlet, and a thermometer, $0.1 \mathrm{~mol}$ of hydroquinone, $0.1 \mathrm{~mol}$ of 4,4'-dichlorodiphenyl sulfone, and $0.15 \mathrm{~mol}$ of $\mathrm{K}_{2} \mathrm{CO}_{3}$ were dissolved in a mixture of NMP-toluene (2:1) by heating (raised to $190^{\circ} \mathrm{C}$ ) and continuous stirring. After a viscous solution was obtained, the reaction was diluted by an appropriate amount of NMP, followed by precipitation by methanol-water (4:1). The synthesized PES was then dried in vacuum at $60{ }^{\circ} \mathrm{C}$ for $24 \mathrm{~h}$. Characterizations were performed by NMR, FTIR, elemental analysis, and DSC. The yield was $68.15 \%$ and the $T_{g}$ was $207.53{ }^{\circ} \mathrm{C}$. Characteristic peaks on the infrared (IR) spectrum were 1327.7 and $1156.7 \mathrm{~cm}^{-1}$ (symmetric stretching of $\mathrm{SO}_{2}$ ), and $1282.1 \mathrm{~cm}^{-1}$ (stretching of $\mathrm{C}-\mathrm{O}-\mathrm{C}$ ). ${ }^{1} \mathrm{H}$ NMR (400 $\mathrm{MHz}$, $d_{6}$-DMSO, $\delta(\mathrm{ppm})$ ): 7.01 and 7.28 (ArH, ortho towards -O-), $7.89\left(\mathrm{ArH}\right.$, ortho toward $\left.-\mathrm{SO}_{2}\right)$. Mass of the repeating unit (MALDI-TOF $m / z)$ : $324 \mathrm{Da}$. Elemental analysis for $\left(\mathrm{C}_{18} \mathrm{H}_{12} \mathrm{O}_{4} \mathrm{~S}\right)_{\mathrm{n}}: 65.47 \% \mathrm{C} ; 3.65 \%$ $\mathrm{H}$; and $9.72 \% \mathrm{~S}$. Calculated results: $65.06 \% \mathrm{C} ; 3.61 \% \mathrm{H}$, and $9.64 \% \mathrm{~S}$.

\subsection{Synthesis of Aminated Polyethersulfone (PES-NH2)}

Aminated Polyethersulfone was produced by a nitration reaction of synthesized PES and followed by a reduction reaction using $\mathrm{SnCl}_{2} \cdot 2 \mathrm{H}_{2} \mathrm{O}$. The nitration of PES was performed by dropwise mixing of concentrated nitric acid-sulfuric acid (4:1) and PES solution (in NMP). During the reaction, the temperature was kept constant $\left(25^{\circ} \mathrm{C}\right)$. The mixture was precipitated in water-methanol $(1: 1)$ to obtain the polymer. The resulting PES- $\mathrm{NO}_{2}$ was then dissolved in NMP and added dropwise into a mixture of $\mathrm{SnCl}_{2} \cdot 2 \mathrm{H}_{2} \mathrm{O}$ and $\mathrm{NaI}(30: 1)$ in $\mathrm{HCl}$ :acetic acid glacial $(2: 1)$ at $60{ }^{\circ} \mathrm{C}$ while stirring for $3 \mathrm{~h}$. The mixture was cooled to room temperature, and precipitated in $2 \mathrm{~N} \mathrm{NaOH}$ solution. The yield was $51.13 \%$ and the $T_{g}$ was $211.27{ }^{\circ} \mathrm{C}$. Characteristic peaks on the infrared (IR) spectrum were 1320.1 and $1152.9 \mathrm{~cm}^{-1}$ (symmetric stretching of $\mathrm{SO}_{2}$ ), $1232.7 \mathrm{~cm}^{-1}$ (stretching of $\mathrm{C}-\mathrm{O}-\mathrm{C}$ ), and 3087.1 (double bands, primary amine, $\left.-\mathrm{NH}_{2}\right) .{ }^{1} \mathrm{H} \mathrm{NMR}(400 \mathrm{MHz}, d$-DMSO, $\delta(\mathrm{ppm}))$ : $4.70\left(-\mathrm{NH}_{2}\right), 7.01$ (ArH, ortho towards -O-, meta towards $-\mathrm{NH}_{2}$ ), 7.05 (ArH, ortho toward $-\mathrm{O}-$ ). 7.10 ( $\mathrm{ArH}$, ortho towards $-\mathrm{SO}_{2}$, ortho towards $\left.-\mathrm{NH}_{2}\right), 7.27$ (ArH, ortho towards $-\mathrm{SO}_{2}$, para towards $\left.-\mathrm{NH}_{2}\right), 7.80$ (ArH, ortho towards $-\mathrm{SO}_{2}$, meta towards -O-). Elemental analysis for $\left(\mathrm{C}_{18} \mathrm{H}_{13} \mathrm{O}_{4} \mathrm{NS}\right)_{\mathrm{n}}: 61.00 \% \mathrm{C} ; 4.54 \% \mathrm{H} ; 2.88 \% \mathrm{~N}$; and $7.99 \%$ S. Calculated results: $62.25 \% \mathrm{C} ; 3.74 \% \mathrm{H} ; 4.03 \% \mathrm{~N}$; and $9.22 \% \mathrm{~S}$.

\subsection{Polyethersulfone Membrane Fabrication}

PES and PES- $\mathrm{NH}_{2}$ membrane were produced by inversion phase technique. PES, DBP as plasticizer, and PEG as pore-sizes controller with various concentrations were prepared as casting solution, then poured onto a glass plate and immediately immersed into a coagulation bath with distilled water. The obtained membranes were characterized by SEM and applied as solid support for 
Mucor miehei lipase immobilization. The compositions of polymer, DBP, and PEG per casting solution are presented in Table 3.

Table 3. Composition of casting solution in membrane fabrication.

\begin{tabular}{ccccc}
\hline No. & Sample Code & \% Polymer $(\mathbf{w} / \mathbf{w})$ & \% DBP $(\mathbf{w} / \mathbf{w})$ & \% PEG $(\mathbf{w} / \mathbf{w})$ \\
\hline 1. & PES-10 & $10(\mathrm{PES})$ & 0 & 0 \\
2. & ComPES-10 & $10(\mathrm{PES} \mathrm{BASF})$ & 0 & 0 \\
3. & PES-10/D4 & $10(\mathrm{PES})$ & 4 & 0 \\
4. & PES-10/D6 & $10(\mathrm{PES})$ & 6 & 0 \\
5. & PES-10/P4 & $10(\mathrm{PES})$ & 0 & 4 \\
6. & PES-10/P6 & $10(\mathrm{PES})$ & 0 & 6 \\
7. & PESNH-10/D5/P2 & $10\left(\mathrm{PES}-\mathrm{NH}_{2}\right)$ & 5 & 2 \\
8. & PESNH-10/D5/P4 & $10\left(\mathrm{PES}-\mathrm{NH}_{2}\right)$ & 5 & 4 \\
9. & PESNH-10/D5/P10 & $10\left(\mathrm{PES}-\mathrm{NH}_{2}\right)$ & 5 & 10 \\
10. & PESNH-10/D2/P5 & $10\left(\mathrm{PES}-\mathrm{NH}_{2}\right)$ & 2 & 5 \\
11. & PESNH-10/D4/P5 & $10\left(\mathrm{PES}-\mathrm{NH}_{2}\right)$ & 4 & 5 \\
12. & PESNH-10/D8/P5 & $10\left(\mathrm{PES}-\mathrm{NH}_{2}\right)$ & 8 & 5 \\
\hline
\end{tabular}

\subsection{Immobilization of Mucor miehei Lipase}

Membranes with certain composition of PES, DBP, and PEG $\left(2 \mathrm{~cm}^{2}\right)$ were mixed with $2 \mathrm{~mL}$ Mucor miehei lipase solution $(2 \mathrm{mg} / \mathrm{mL})$ in a PBS buffer $(\mathrm{pH} 7)$. The samples were incubated in a rotary shaker at $30{ }^{\circ} \mathrm{C}$ at $200 \mathrm{rpm}$ for $24 \mathrm{~h}$. Separation of the immobilized enzyme and the supernatant was performed by filtration. The immobilized Mucor miehei lipase was washed with PBS buffer and distilled water, until no further protein was detected in the solution. The supernatant and washing solutions were tested by a bicinchoninic acid (BCA) protein assay for determination of the amount of attached protein using UV/VIS spectrophotometer at the $\lambda_{\max }(352 \mathrm{~nm})$. The immobilized lipases obtained were dried by liquid nitrogen and kept in a vacuum oven for $24 \mathrm{~h}$ at room temperature.

\subsection{Transesterification Activity Test}

1,4-dioxane solution $(5 \mathrm{~mL})$ containing $p$ NPA $(40.0 \mathrm{mM})$ and methanol $(80.0 \mathrm{mM})$ was added into $20 \mathrm{~mL}$ vials containing $0.772 \mathrm{mg}$ of enzyme. The reaction was carried out for $50 \mathrm{~min}$ at $35{ }^{\circ} \mathrm{C}$ (300 rpm) and terminated by filtration of the enzyme. The product concentration of $p$-nitrophenol ( $p \mathrm{NP}$ ) was determined by UV/VIS spectrophotometer at the $\lambda_{\max }$ of $p \mathrm{NP}(304 \mathrm{~nm})$. Hydrolytic activities of free lipase, lipase immobilized onto PES membrane, and lipase immobilized onto PES- $\mathrm{NH}_{2}$ membrane are defined as the millimoles of $p \mathrm{NP}$ in 1,4-dioxane per unit of weight of enzyme per time ( $\mathrm{mmol}$ of $p \mathrm{NP} / \mathrm{mg} / \mathrm{min})$.

\subsection{Reusability Test}

Reusability tests were carried out on the free lipase, the immobilized lipase onto PES, and the immobilized lipase onto PES- $\mathrm{NH}_{2}$. During these tests, the reaction between $p \mathrm{NPA}$ and methanol in 1,4-dioxane was followed using the same composition as in the hydrolytic activity test. After the UV 
measurements, all the immobilized enzymes were washed with 1,4-dioxane, dried and kept under vacuum for $24 \mathrm{~h}$. The immobilized lipases were reused four times.

\section{Conclusions}

Polyethersulfone (PES) and aminated PES (PES- $\left.\mathrm{NH}_{2}\right)$ were successfully synthesized and could be applied as a solid support for Mucor miehei lipase immobilization. The composition of the casting solution for the membrane preparation strongly influenced the membrane characteristics, enzyme loading, and hydrolysis activity of the enzyme. According to the results of reusability tests, the immobilized lipase on a PES- $\mathrm{NH}_{2}$ membrane showed higher reusability than the immobilized lipase on a PES membrane.

\section{Acknowledgments}

We are indebted to Yana Maolana Syah, Fida Madayanti Warganegara, Henk Miedema, Arie Zwijnenburg, Anna Casadella, and Megawati Zunita for their kind cooperation. We greatly appreciate the assistance of Gert Alberda for thermal analysis, Evgeny Polushkin for SEM analysis, Annie van Dam and Hjalmar Permentier for MALDI-TOF analysis. Vincent Voet is acknowledged for his careful revision of the current manuscript.

\section{References}

1. Worsfold, P.J. Classification and chemical characteristics of immobilized enzymes. Pure Appl. Chem. 1995, 67, 597-600.

2. Vandamme, E.J. Peptide antibiotic production through immobilized biocatalyst technology. Enzym. Microb. Technol. 1983, 5, 403-415.

3. Miletic, N.; Nastasovic, A.; Loos, K. Immobilization of biocatalysts for enzymatic polymerizations: Possibilities, advantages, applications. Bioresour. Technol. 2012, in press.

4. Schulze, B.; Wubbolts, M.G. Biocatalysis for industrial production of fine chemicals. Curr. Opin. Biotechnol. 1999, 10, 609-615.

5. Clark, L.C.; Lysons, C. Electrode systems for continuous monitoring in cardiovascular surgery. Ann. N. Y. Acad. Sci. 1962, 4, 29-45.

6. Cristallini, C.; Lazzeri, L.; Cascone, M.G.; Polacco, G.; Lupinacci, D.; Barbani, N. Enzyme-based bioartificial polymeric materials: The $\alpha$-amylase-poly (vinyl alcohol) system. Polym. Int. 1997, 44, 510-516.

7. Weisse, H.; Keul, H.; Hocker, H. A new route to carboxylated poly(ether sulfone)s: Synthesis and characterization. Polymer 2001, 42, 5973-5978.

8. Sinisterra, J.V.; Moreno, J.M. Immobilization of lipase from Candida cylindracea on inorganic supports. J. Mol. Catal. 1994, 93, 357-369.

9. Kumakura, M.; Kaetsu, I. Immobilization of enzymes masks their active site. Biosci. Rep. 1984, 4, $181-187$.

10. Reetz, M.T.; Jaeger, K.E. Overexpression, immobilization, and biotechnological apllication of Pseudomonas lipases. Chem. Phys. Lip. 1998, 93, 3-14. 
11. Garcia-Galan, C.; Berenguer-Murcia, A.; Fernandez-Lafuente, R.; Rodrigues, R.C. Potential of different enzyme immobilization strategies to improve enzyme performance. Adv. Synth. Catal. 2011, 353, 2885-2904.

12. Derewenda, Z.S.; Derewenda, U.; Dodson, G.G. The crystal and molecular structure of the Rhizomucor miehei triacylglyceride lipase at 1.9 Å resolution. J. Mol. Biol. 1992, 227, 818-839.

13. Reis, P.; Holmberg, K.; Watzke, H.; Leser, M.E.; Miller, R. Lipases at interfaces: A review. $A d v$. Colloid Interface Sci. 2009, 147-148, 237-250.

14. Miled, N.; Beisson, F.; De Caro, J.; De Caro, A.; Arondel, J.; Verger, R. Interfacial catalysis by lipases. J. Mol. Catal. B Enzym. 2001, 11, 165-171.

15. Iyer, P.V.; Ananthanarayan, L. Enzyme stability and stabilization-Aqueous and non-aqueous environment. Process Biochem. 2008, 43, 1019-1032.

16. Rodrigues, R.C.; Berenguer-Murcia, Á.; Fernandez-Lafuente, R. Coupling chemical modification and immobilization to improve the catalytic performance of enzymes. Adv. Synth. Catal. 2011, $353,2216-2238$.

17. Hernandez, K.; Fernandez-Lafuente, R. Control of protein immobilization: Coupling immobilization and site-directed mutagenesis to improve biocatalyst or biosensor performance. Enzym. Microb. Technol. 2011, 48, 107-122.

18. Fernandez-Lafuente, R. Stabilization of multimeric enzymes: Strategies to prevent subunit dissociation. Enzym. Microb. Technol. 2009, 45, 405-418.

19. Brady, D.; Jordaan, J. Advances in enzyme immobilization. Biotechnol. Lett. 2009, 31, 1639-1650.

20. Betancor, L.; Luckarift, H.R. Bioinspired enzyme encapsulation for biocatalysis. Trends Biotechnol. 2008, 26, 566-572.

21. Mateo, C.; Palomo, J.M.; Fernandez-Lorente, G.; Guisan, J.M.; Fernandez-Lafuente, R. Improvement of enzyme activity, stability and selectivity via immobilization techniques. Enzym. Microb. Technol. 2007, 40, 1451-1463.

22. Giorno, L.; Drioli, E. Biocatalytic membrane reactors: Applications and perspectives. TIBTECH 2000, 18, 339-349.

23. Stamatoglou, S.C.; Keller, J.M. Correlation between cell substrate attachment in vitro and cell surface heparan sulfate affinity for fibronectin and collagen. J. Cell Biol. 1983, 96, 1820-1823.

24. Wolf, M.G.; Hoefling, M.; Aponte-Santamaria, C.; Grubmüller, H.; Groenhof, G. Efficient insertion of a membrane protein into an equilibrated lipid bilayer with minimal perturbation. J. Comp. Chem. 2010, 31, 2169-2174.

25. Tosa, T.; Mori, T.; Fuse, N.; Chibata, I. Studies on continuous enzyme reactions. IV. Preparation of a DEAE-sephadex-aminoacylase column and continuous optical resolution of acyl-DL-amino acids. Biotech. Bioeng. 1967, 9, 603-615.

26. Sewalt, J.J.; Padt van der, A.; van't Riet, K. Potential effect of the membrane potting on the long-term performance during hydrolysis of edible oil. J. Membr. Sci. 2000, 164, 79-88.

27. Shau-wei, T.; SaN-syan, S. Selection of hydrophobic membranes in the lipase-catalyzed hydrolysis of olive oil. J. Membr. Sci. 1998, 146, 1-8.

28. Pozniak, G.; Krajewska, B.; Trochimczuk, W. Urease immobilized on modified polysulphone membrane: Preparation and properties. Biomaterials 1995, 16, 129-134. 
29. Nelson, L.A.; Foglia, T.A.; Marmer, W.N. Lipase-catalyzed production of biodiesel. JAOCS 1996, 73, 1191-1195.

30. Schmid, R.D.; Verger, R. Lipases: Interfacial enzymes with attractive applications. Angew. Chem. Int. Ed. 1998, 37, 1608-1633.

31. Edmundo, C.; Valerie, D.; Didier, C.; Alain, M. Efficient Lipase-catalyzed production of tailor-made emulsifier using solvent engineering coupled to extractive processing. JAOCS 1998, 75, 309-313.

32. Linder, M.; Kochanowski, N.; Fanni, J.; Parmentier, M. Response surface optimisation of lipase-catalysed esterification of glycerol and n-3 polyunsaturated fatty acids from salmon oil. Process Biochem. 2005, 40, 273-279.

33. Hills, G. Industrial use of lipases to produce fatty acid esters. Eur. J. Lipid Sci. Technol. 2003, 105, 601-607.

34. Athawale, V.; Manjrekar, N.; Athawale, M. Effect of reaction parameter on synthesis of citronellyl methacrylate by lipase-catalyzed transesterification. Biotechnol. Prog. 2003, 19, 298-302.

35. Kumar, A.; Gross, R.A. Candida antarctica lipase B-catalyzed transesterification: New synthetic routes to copolymes. J. Am. Chem. Soc. 2000, 122, 11767-11770.

36. Gandhi, V.M.; Cherian, K.M.; Mulky, M.J. Nutritional and toxicological evaluation of rubber seed oil. JAOCS 1990, 67, 883-886.

37. Sonnet, P.E.; Moore, G. Esterification of 1- and rac-2-octanols with selected acids and acid derivatives using lipases. Lipids 1988, 23, 955-996.

38. Brady, L.; Brzozowski, A.M.; Derewenda, Z.S.; Dodson, E.; Dodson, G.; Tolley, S.; Turkenburg, J.P.; Christiansen, L.; Huge-Jensen, B.; Norskov, L.; Thim, L.; Menge, U. A serine protease triad forms the catalytic centre of a triacylglycerol lipase. Nature 1990, 343, 767-770.

39. Keitoku, F.; Kakimoto, M.A.; Imai, Y. Synthesis and properties of aromatic poly(ether sulfone)s and poly(ether ketone)s based on methyl-substituted biphenyl-4,4'-diols. J. Polym. Sci. A Polym. Chem. 1994, 32, 317-322.

40. Handayani, N.; Buchari; Wahyuningrum, D.; Zulfikar, M.A. Sintesis dan karakterisasi poli (eter-sulfon) dan poli (eter-sulfon) ternitrasi sebagai material membran untuk imobilisasi lipase [Bahasa].J. Kimia Indones. 2010, 5, 7-16.

41. Knezevic, Z.D.; Siler-Marinkovic, S.; Mojovic, L. Kinetics of lipase-catalyzed hydrolysis of palm oil in lecithin/izooctane reversed micelles. Appl. Microbiol. Biotechol. 1998, 49, 267-271.

42. Sho, M.T.; Eirich, F.R.; Strathmann, H.; Baker, R.W. Preparation of asymmetric loeb-sourirajan membranes. J. Polym. Sci. Polym. Lett. Ed. 1973, 11, 201-205.

43. Marsman, D.S. NTP technical report on the toxicity studies of dibutyl phthalate (CAS No. 84-74-2) administered in feed to F344/N rats and B6C3F1 mice. NTP Toxic. Rep. 1995, 30, 1-G5.

44. Handayani, N.; Miletic, N.; Loos, K.; Achmad, S.; Wahyuningrum, D. Properties of immobilized Candida antarctica lipase B on highly macroporous copolymer. Sains Malays. 2011, 40, 965-972.

45. Miletic, N.; Vukovic, Z.; Nastasovic, A.; Loos, K. Macroporous poly (glycidyl methacrylate-co-ethylene glycol dimethacrylate) resins-Versatile immobilization supports for biocatalysts. J. Mol. Catal. B Enzym. 2009, 56, 196-201. 
46. Miletic, N.; Rohandi, R.; Vukovic, Z.; Nastasovic, A.; Loos, K. Surface modification of macroporous poly(glycidyl methacrylate-co-ethylene glycol dimethacrylate) resins for improved Candida antarctica lipase B immobilization. React. Funct. Polym. 2009, 69, 68-75.

47. Miletic, N.; Loos, K. Over-stabilization of chemically modified and cross-linked candida antarctica lipase B using various epoxides and diepoxides. Aust. J. Chem. 2009, 62, 799-805.

48. Benaki, D.C.; Anggeli, A.; Chryssikos, G.D.; Yiannopoulos, Y.D.; Kamitsos, E.I.; Brumley, E.; Case, S.T.; Boden, N.; Hamodrakas, S.J. Laser-raman and FT-IR spectroscopic studies of peptide analogues of silkmoth chorion protein segments. Int. J. Biol. Macromol. 1998, 23, 49-59.

(C) 2012 by the authors; licensee MDPI, Basel, Switzerland. This article is an open access article distributed under the terms and conditions of the Creative Commons Attribution license (http://creativecommons.org/licenses/by/3.0/). 